\title{
De Fausto a Fausto: 0 gaúcho na ópera
}

No era un Dotor muy projundo? Cómo se dejo engañar?

Ligia Chiappin Moraes Lette

Brasilianistik/Lateinamerika Institut- Freie Universität-Berlin e Universidade de São Paulo
Resumo

O texto analisa o Fausto, poema gauchesco de Estanislao del Campo, em comparaçāo com a ópera de Gounod e a primeir parte do drama de Goethe, o Fausto I, indagando do lugar dessa paródia no sistema literário da gauchesca platina e as possiveis significaçōes que ele pode ter para pensar a modernizaçāo na Argentina em plena guerra do Paraguai.

\section{Abstract}

The text analyzes Fausto, a gauchesco poem by Estanislao del Campo, and compares it with Gounod's opera and the first part of Goethe's drama, Faust I, probing the place of this parody in the literary system of the River Plate gauchesca and its possible contribution to a reflection on modemization in Argentina in the midst of the Paraguayan War.

\author{
Polovias-chave \\ Fausto, \\ Goethe, \\ Gounod, \\ Estanislao del \\ Campo, \\ gauchesca, \\ modernizaçāo, \\ campo e \\ cidade, Rio da \\ Praca.
}

Keywords

Faust; Goethe;

Gounod;

Estanislao del

Campo;

gauchesca;

modernization;

country and

city; River

Plate.
Texto publicado originalmente pela editora Abya-Yala, de Quito, Equador, no livro organizado por Luiza Lobo, intitulado Modemidad y modernización, cultura y literatura en Latinoamerica (2000, p. 47-80). Agradeço as sugestōes recebidas na ocasiāo pela organizadora do volume e por Marily Martinez Richter.
(Estanislao del Campo, Fausto.) chama atençāo para a atualidade do mito fáustico na Alemanha, onde, em suas recentes pesquisas, viu "faustos brotando em toda parte". Segundo ela, nenhum tema é tāo vivo como "essa história de amor e morte, de confronto com a eternidade e a salvação, de comércio com as forças do mal que vem de tempos muito distantes, ligando-se a narrativas longínquas e dispersas, algumas delas da primeira literatura cristã". ${ }^{2}$

A pesquisadora chama atenção para as recriações do Fausto através dos mais diversos meios, tais como o teatro, o cinema e o vídeo, atualizando-se assim para a imaginaçāo dos europeus. Mas nāo só. Também do outro lado do mar, o tema não deixa de estar presente e é reencontrado nas ediçoses populares e, entre elas, o cordel. Sobre a presença do mito na América Latina, diz Jerusa Ferreira:

No caso das culturas populares e de massas na América Latina, há sempre o texto fáustico apelando para suas origens, agrupando legendas conexas sedimentadas na memória e também processando novas criaçöes, principalmente a partir do tamoso e insubstituivel texto de Goethe, matriz permanente para novos textos. O Fausto explode em composiçōes gauchescas, em ediçōes facilitadas e populares brasileiras, vai ao encontro das estórias de pacto que formam aquilo que se chamou "ciclo do demônio logrado", no universo do conto oral e da literatura de folhetos - cordel - , ainda hoje. ${ }^{3}$

Também no Sul do país o pactário se faz presente. Jerusa nos diz que "é muito bem realizada em dialeto gauchesco a tradiçāo do Fausto popular", destacando, como ponto alto dessa tradiçāo, para além das fronteiras políticas nacionais, o

${ }^{1}$ Jerusa Pires Ferreira, Fausto no horizonte, razōes míticas, texto oral, ediçōes populares, São Paulo, Hucitec, 1990.

Idem, ibidem, p. 11 .

${ }^{3}$ Idem, ibidem, p. 12 
Fausto de Estanislao del Campo. Como a ópera de Gounod, de que falaremos mais adiante, o poema gauchesco também tornou-se muito popular. A esse respeito, diz Borges: "Ha logrado el poema, en estas repúblicas del Sur, extraordinaria difusión oral: suele asomar en la conversación y está vivo en muchas memorias".

E recentemente, o grupo argentino, sob a direçāo de Alfredo Arias, levou para Paris o Faust Argentin, Musical transatlantique, apresentado lá em novembro e dezembro de 1995. Alfredo Arias, como Mefistófeles, mistura aí suas próprias imagens às da lenda diabólica revisitada por aquele poeta argentino do século passado. O poema gauchesco é submetido a uma adaptação local e temporal, com os recursos do nosso tempo: music-hall, tango, bolero, folclore do pampa, danças e acrobacias, integrando-se para compor o que se definiu como "uma viagem no delírio".

Este ensaio se propõe a analisar um pouco mais de perto o poema de Estanislao del Campo, pois, apesar de suas inúmeras ediçōes e adaptaçôes, bem como do apreço que um escritor do porte de Borges lhe dedica, nāo parece ter sido objeto de estudos mais aprofundados, porque geralmente é considerado como uma espécie de brincadeira inconseqüente, quase herético com relação a uma obra clássica como a de Goethe.

Trata-se de um poema narrativo, em que um gaúcho, voltando de Buenos Aires, conta a um parceiro o que lá viu, mais propriamente, o que viu no teatro Colón, a história de Fausto e Margarida. Na verdade, o que teria visto no teatro seria a representação da ópera Fausto, de Gounod, ${ }^{5}$ que, alguns meses antes da publicação do poema, havia efetivamente sido representada nessa cidade. Boa parte da graça do poema vem do fato de que Anastasio el Pollo, o narrador, refere a história de Fausto e do pacto com o diabo como se fosse real e seu interlocutor, Laguna tece comentários incrédulos todo o tempo, mas acredita tanto quanto Pollo em que se trata de algo realmente acontecido diante dos olhos do amigo. Atualizaçōes como a que faz do irmāo de Margarida, Valentin, um soldado da Guerra do Paraguai, também concorrem para o efeito cômico.

Udo Rukser, no seu livro intitulado Goethe en el Mundo Hispânico, ${ }^{6}$ é um dos primeiros a formular esse juízo. Diz ele, falando das retomadas satíricas do poema de Goethe nos países de língua espanhola:

no faltan tampoco imitaciones grotescas: el eco de la pampa argentina en Fausto [...] Margarita se convierte en rancherita, $y$ Valenttn en un soldado que participa en la guerra contra Paraguay en tanto que la bodega de Auerbach es una taberna en la pampa; en esta forma, todo resulta no solo nacionalizado, sino "localizado", y aun, con frecuencia, de la manera más ridicula y con las comparaciones más extravagantes.?

“ Jorge Luis Borges, El Martin Fierro, Buenos Aires, Columbia, p. 15.

5 "Fausto" é uma ópera em cinco atos, com música de Gounod, livreto de Jules Barbier e Michel Carré, baseada no Fausto de J. W. Goeche. Estreou em 19 de março de 1859 no Teatro Lírico de Paris. Foi apresentada no teatro Colón, de Buenos Aires, poucos meses antes da publicaçăa do poema de Estanislao del Campo, em agosto de 1866.

${ }^{6}$ Udo Rukser, Goethe en el mundo hispânico, México, Madrid, Buenos Aires, Fondo de Cultura Económico, 1958.

${ }^{7}$ Idem, ibidem, p. 154.
Mas o desprezo do crítico por essa obra, para ele visivelmente destituída de valor estético, parece relativizar-se quando, a seguir, reflete sobre a circularidade aí revelada entre a tradiçāo culta e a popular, embora também a reapropriação do poema clássico pela tradiçāo popular represente para ele uma espécie de queda:

Aun cuando la obrita recuerda ciertos cuentos homipilantes, lo cierto es que la evolución y la transformación del tema presentam un carácter curioso: Goethe lo tomó de las barracas de las ferias locales y la plasmó de la manera más sublime, después que muchos otros la habtan trabajado. Pero desde esta altura volvió luego a descender lentamente hasta llegar de nuevo, en los antípodas, al nivel de la feria local. ${ }^{8}$

Na verdade, há aí pelo menos duas confusỏes que o autor, no tempo em que escreveu seu excelente livro (1958), nāo poderia talvez evitar. De um lado, nāo se trata de um poema propriamente nacional, na medida em que, embora se passe nos arredores de Buenos Aires, enquadra-se na tendência mais geral da gauchesca que acaba transpondo fronteiras na "comarca" cultural do pampa brasileiro, uruguaio e argentino. De outro, tampouco se trata de uma literatura popular, como a das feiras, mas uma literatura de caráter híbrido, intencionalmente situada entre o culto e o popular, feita por escritor culto e citadino, mas que conheceu a fundo a vida do gaúcho pobre e se familiarizou suficientemente com sua linguagem e seu imaginário para poder estabelecer uma espécie de ponte entre o universo do gaúcho, com seus próprios valores, e a requintada cultura européia.

Jorge Luis Borges, que já fazia essas distinçōes todas na mesma época, assim responde às criticas de falta de autenticidade principalmente da idéia de pôr um gaúcho no teatro Colón, mas também do que Udo Rukser chamou de extravagâncias. Diz Borges:

Algunos detractores - Rafael Hernandez, hermano de José, fue tal vez el primero - han acusado a Estanislao del Campo de no conocer al gaucho. Hasta el pelo del caballo del heroe ha sido examinado y reprobado. Tales censuras importan un anacronismo. En mil ochocientos sesenta y tantos, en Buenos Aires, lo dificil no era conocer al gaucho, sino ignorarlo. La campaña se confudia con la Buenos Aires, lo dificil no era conocer al gaucho, sino ignorarlo. La campaña se confudia con la
ciudad y su plebe era criolla, Además, el coronel Estanislao del Campo se batio en el sitio de Buenos Aires, en Pavón, en Cepeda y en la revolución de 74:10 la tropa comandada por el y particularmente la caballeria, era gaucha. Los emrores que se han advertido en el Fausto son distracciones, debidas precisamente al desahogo de quien está tratando una materia que conoce mui bien y no se demora en la verificación de detalles. ${ }^{11}$

Borges responde especialmente a Leopoldo Lugones, o que the permite utilizar um argumento mais interno à obra como convençāo verossímil. Diz ele:

${ }^{8}$ Idem, ibidem, p. 154

${ }^{9} \mathrm{O}$ termo é de Angel Rama,

${ }^{10}$ Sítio de Buenos Aires, 1852 (Buenos Aires se havia separado da Confederaçāo Argentina); Batalha de Cepeda, 1859, em que Mitre é derrotado por Urquiza; combate de Pavón, 1861. Urquiza é derrotado por Mitre. Revolución de 74, contra os rebeldes chefiados por Mitre para impedir Nicolás Avellaneda de tomar posse.

${ }^{11}$ Jorge Luis Borges, El Martin Fierro, op. cit., p. 15. 
Lugones censura este argumento: "Ni el gaucho habria entendido una palabra, ni habria aguantado sin dormirse $\boldsymbol{o}$ sin salir, aquella música para el atroz: ni siquiera es concebible que se le antojara a un gaucho meterse por su cuenta a un teatro lirico" (el Payador, 157) A esto cabria responder que todo arte, aun el naturalista, es convencional y que las convenciones de aceptación más fácil son las que pertenecen al planteo mismo de las obras: v.g. la "ilusión cómica" de Anastasio o la extrema autobiografia rimada de Martín Fierro. Si nos resolvemos, para usar la frase de Coleridge, a suspender nuestra incredulidad, obtenemos un admirable poema. En sus contada páginas abundan las descripciones felices, como la del amanecer y la de la noche, los rasgos pintorescos, las bondadosas malicias $y$ las digresiones patéticas. (p. XV)

Admitindo a hipótese de Lugones de que um gaúcho não poderia seguir os episódios de uma ópera e não suportaria a música, Borges julga, entretanto, mais importante que a discordância sobre o cavalo "overo rosado", que não poderia ser parelheiro, a cordialidade do poema. E elenca como virtude central dele a amizade que o diálogo dos parceiros traduz, além de destacar outros aspectos, entre eles as descriçōes felizes, como a do amanhecer e as digressões poéticas, como a do amor. ${ }^{12}$

Borges abre aqui uma discussāo que jâ encontramos no Brasil freqūentemente a propósito de José de Alencar, sobre a inverossimilhança, por exemplo, de O guarani ou de $O$ gauicho. ${ }^{13} \mathrm{E}$ direciona a discussāo nāo para a semelhança com a realidade, mas para a coerência interna e a realização estética, tornando aceitável aquilo que, sob o prisma de um realismo estreito, se leria como disparate ou extravagância. Mas, enquanto Antonio Candido, no caso brasileiro, defendendo os árcades ou José de Alencar, explicita essa diferença, Borges apenas a sugere. Por isso, nos deixa caminho para tentar ęxplicar por onde passa esse trabalho de criação da verossimilhança.

Para explicá-lo teremos de analisar melhor o poema, tendo como mediação o primeiro Fausto. Assim, talvez possamos entender melhor o que quer Borges dizer com "broma general de la obra", de um lado, e, de outro, com "Ia cordialidad del poema, la amistad traducida por el dialogo entre los dos parceros". Ai estariam duas características opostas conjugadas, o lado cômico e o lado sério. Uma das tarefas da crítica seria ver como isso se dá, para o que é preciso comparar a ópera e o poema, mediados pela referência comum ao texto de Goethe.

\section{A ópera ${ }^{14}$}

“Está provado que só é possivel filosofar em alemāo"

(Caetano Veloso)

O Fausto, de Gounod, nāo teve êxito imediato na sua estréia parisiense, mas foi ganhando o público pouco a pouco, tendo conquistado inteiramente a Europa toda em relativamente curto espaço de tempo. Na verdade, Gounod musicou um

${ }^{12} \mathrm{Idem}$, ibidem.

${ }^{3}$ Ver capitulo sobre José de Alencar em Antonio Candido, A formaçāo da literatura brasileira, Belo Horizonte, Rio da Janeiro, Itatiaia, 1993.

${ }^{14}$ Muitas das reflexōes desta parte me foram inspiradas pela belissima aula que Ênio Squeff generosamente me deu sobre a ópera de Gounod. Ficam aqui meus calorosos agradecimentos. livreto, escrito por Jules Barbier e Michel Carré e inspirado na primeira parte do Fausto de Goethe. Nessa primeira parte aparece o velho sábio, Fausto, cético em relaçāo à sabedoria humana, desesperançado em encontrar sentido para a vida. Desse modo, torna-se presa fácil de Mefistófeles, que o persuade a vender sua alma em troca da juventude. Mefistófeles acaba persuadindo Fausto, ainda hesitante, apresentando-lhe a imagem fulgurante de beleza de Helena, símbolo do eterno feminino, e mais adiante como que reencarnada em Margarida. Essa é uma pobre moça, seduzida pelos encantos e presentes de Fausto já rejuvenescido. No final, Margarida, abandonada, mata o próprio filho e morre. Mefistófeles afirma que ela está julgada, mas uma voz celeste afirma que ela está salva. Em compensação, Fausto fica com Mefistófeles, o que sugere a sua condenação eterna, ao contrário do poema de Goethe, onde Fausto também morre no final, mas sua alma se salva. Isso ocorre, porém, no segundo Fausto, do qual a ópera parece não tomar conhecimento, como a maior parte das adaptações e traduções do famoso poema de Goethe. Nesse, numa segunda parte bastante hermética e alegórica, podemos acompanhar justamente a gradual redençāo de Fausto, o que ele consegue, demonstrando seu amor à humanidade e sua capacidade de luta.

Ernest Newman, em História das grandes óperas, conta-nos que a ópera de Gounod foi, no início, uma opéra comique, o que significa ter partes líricas entremeadas com diálogos falados. Mas, na encenação parisiense, de 3 de março de 1869 , as partes faladas teriam sido substituidas por música e seria nessa forma que a ópera teria chegado a nós.

A história do libretista, Barbier, e de suas dificuldades em encontrar músico famoso para compor a partitura da ópera já nos mostra como a simples passagem do poema de Goethe ou de parte dele para esse gênero era considerada uma espécie de heresia. É o que teria feito Meyerbeer recusar-se, como alemāo que cultuava a memória do clássico, "converter o grande poema nacional num vulgar espetáculo teatral". ${ }^{15}$ Pois um francês o fez $e$, com ele, o

Fausto tornou-se tāo farniliar no mundo modemo, e tantas cousas sucederam em maréria de música desde 1859, que basta um pequeno esforço de imaginaçāo para compreender o efeito de música desde 1859 , que basta um pequeno esforço de imaginaca
avassalador que a ópera produziu na geraçāo em que apareceu.

Para o seu tempo foi um trabalho muito original e grandemente revolucionário. Os alemães mais sérios fizeram o possivel para amesquinhä-lo; não se conformavam com o tratamento tāo acentuadamente sensual de um assunto que, para eles, era, acima de tudo, espiritual e filosófico. Apesar disso, porém, nada conseguiu deter a marcha triunfal da ópera, mesmo na Alemanha. ${ }^{16}$

Deixando de lado a segunda parte, como vimos, a ópera aproveita do poema de Goethe apenas o miolo da primeira parte: o rejuvenescimento após o pacto com o demônio, a conquista e abandono de Margarida, a redenção desta apesar do seu crime e a aparente condenação de Fausto nas mãos de Mefistófeles. Gounod e

${ }^{15}$ Emest Newman, História das grandes óperas e de seus compositores, trad. Antônio Dias e Joāo Henrique Chaves, Porto Alegre, Globo, 1946-1952, p. 134

${ }^{16}$ Idem, ibidem, p. 137. 
seus libretistas também nāo tomam conhecimento do início do poema, onde se dã a aposta de Deus com Mefistófeles sobre a capacidade ou incapacidade de o sábio resistir às tentacōes do demo e continuar a defender os valores divinos. Nem poderia deixar de ser assim, na medida em que essa aposta só se resolve no Fausto 2, quando, apesar de pecador, a superioridade espiritual de Fausto o leva também à salvaçāo.

Todo o significado místico e filosófico do poema ter-se-ia, assim, perdido na ópera. Toda a problematização dos limites da razāo humana, igualmente. Mas algo dessa dimensāo se recuperaria pela música, com um adágio que começa com um acorde fortíssimo e continua "pelo desdobramento pianissimo de um tema contemplativo", fazendo lembrar a todo momento a música religiosa de Gounod. Diz Newman, "mais uma vez, vemos como Gounod encontra prontamente a expressāo verdadeira de um sentimento religioso", referindo-se aos quatro compassos de música coral nāo acompanhada com os quais todos rezam pela paz de Valentim, o soldado, irmão de Margarida, recém-morto. ${ }^{17}$ Cantos de saudades, alegres danças, acordes sinistros, cançōes de louvor à bebida e ao amor, alegria infernal da orquestra, leitmotivs musicais à moda wagneriana, com destaque para alguns fragmentos, como a famosa área das jóias, tentam pintar dramaticamente, com maior ou menor êxito, os lances da tragédia de Fausto e Margarida.

José Avinoa ${ }^{18}$ nos alerta para as críticas que a ópera recebeu depois de tanto êxito junto ao público da época, sobretudo pela pobreza do livreto, visto, em relação ao original, como grosseira imitação dos valores literários desse, aproveitando os aspectos sentimentais e esquecendo os profundos conteúdos arquitetípicos que Goethe pretendia incutir na sua personagem:

$\mathrm{Na}$ opiniāo de certa crítica contemporânea, Gounod também não realizou uma açāo criativa. Segundo este ponto de vista, o Fausto gounodiano é uma castraçāo das virtudes e defeitos da principal personagem, que fica convertida numa espécie de bobalhão namoradeiro e irresponsável. Mefistófeles num vulgar alcaiote de conduta nāo muito afastada de certas concepções teatrais de recorte popular e Margarida numa moça indefesa vítima das ciladas do mal, sem vontade nem personalidade próprias. ${ }^{19}$

Mas José Avinoa, embora reconheça um fundo de verdade nessas críticas, já que "os livretos de ópera românticos consistiam principalmente em servir de pretexto para o drama musical", entende que nāo dá para avaliar a ópera pelo livreto. Tratando-se de um novo gênero em que a música é fundamental, é preciso levá-la em conta, assim como "o canto, a orquestração, a dinâmica coral, o contexto dramático, criado pelo conjunto de ingredientes presentes na obra, que continuam a atrair enormes massas de apreciadores aos teatros de todo o mundo". ${ }^{20}$

${ }^{17} \mathrm{Idem}, \mathrm{ibidem}, \mathrm{p} .156$

${ }^{18}$ Fausto, Livreto com texto em francês, de Jules Barbier e Michel Carré, introduçāo, análise e comentários: José Avinoa, "Fausto em português": Fernando Pires, traduçāo: Eduardo Salo, coordenação, Fernando Pires, Ed. Notícias, Lisboa, s. d

${ }^{19}$ Idem, ibidem, p. 14

${ }^{20}$ Idem, ibidem, p. 14
Do trabalho de Gounod, como músico, ressalta o brilho, "com sua expressão melódica entre açucarada e expressiva, quase patética, impressionista, se se quiser, mas profundamente comunicativa".21

Concorda ainda que a obra se faz aos saltos, sem coerência no argumento, que é superficial nas descriçōes, que os personagens são ingênuos e com pouca consistência dramática, mas entende que tudo isso é "compensado pelos episódios cantábiles, melhores exemplos do bel canto operístico". Reconhece uma capacidade de tradução, em linguagem de canto operístico, das tensōes e sentimentos da peça de Goethe.

Assim é preciso entender que a tradução para o gênero ópera implicou uma adaptaçāo $e$, conseqüentemente, o respeito às normas da época para obras desse gênero. Era frequenente a escolha de grandes obras da literatura para criar uma ópera, sintetizando a ação ao máximo, mal costurando episódios meio soltos e realçando alguns momentos privilegiados que se transformariam nos cantábiles, tão apreciados pelos espectadores do tempo.

Na verdade, a ópera realiza também uma espécie de popularização que, no caso de obras como Fausto, retoma a origem popular do mito. Como se sabe, o mito fáustico existia na tradiçāo oral, supostamente a partir de um fato real, ou da existência de Johann Faust, doutor pela Universidade de Heildelberg em 1509. Passando por várias versōes escritas, sendo a mais famosa antes da de Goethe, a de Marlowe, de 1604, acaba chegando à versāo alemā, primeiro no Ur-Fausto, de 1775 , depois na primeira parte do poema que conhecemos hoje, publicada em 1807 e, apenas 24 anos mais tarde, já na velhice de Goethe, a segunda parte, sendo a primeira centrada na terra e a segunda, no céu. Especialmente a primeira parte é retomada por vários músicos famosos, entre eles Schubert, Berlioz e Wagner. A partir do Romantismo começa esse movimento de repopularização do mito. A versão operística de Gounod contribui para esse processo, deixando de lado muitas sutilezas do sofisticado texto alemāo. A semelhança com Goethe restringe-se ao esquema dramático. Longas reflexões do desesperado pactário resumem-se na ópera, a um canto desesperado. Episódios são eliminados, mesmo na primeira parte, como o aparecimento do diabo disfarçado em cāo, antes de identificar-se para Fausto. Em compensaçāo, a ópera compraz-se em alongar o episódio de seduçāo de Margarida.

Algumas mudanças introduzidas nas personagens também decorrem da necessidade de adaptação ao novo gênero. No original, a māe de Margarida não morreu, mas na ópera ela precisa morrer para acentuar o desamparo da jovem e para dar lugar de destaque à vizinha Marta, a alcoviteira, que forma um bom par com Mefistófeles, par cômico responsável por muitas cenas engraçadas meio século depois, no filme de Murnau.

Uma personagem que não tinha relevo maior no poema de Goethe, Siebel, vira um pretendente de Margarida e contraponto dramático na situacão amorosa. O contraponto se faz também pelo canto, pois, enquanto Fausto é tenor, Siebel é barítono.

${ }^{21}$ Idem, ibidem, p. 14 
O poema de Goethe é contínuo. Já o livreto é dividido em cinco atos. Mas os cinco atos eram outro padrāo da grande ópera. O primeiro ato contrasta o desespero de Fausto às cantorias do povo lá fora, indo ao trabalho. Narra a seguir a chegada de Mefistófeles e o pacto selado, num canto triunfal de Fausto e do Diabo. Aí, o que no livreto parece mera redundância, na execuçāo musical ganha especial força no canto dionisíaco da dupla pactária que se constrói num crescendo desafiador. ${ }^{22}$ Segundo José:

O Fausto de Gounod esqueceu o profundo pensador de Goethe, que se interroga sobre todos os grandes temas teológicos e filosóficos até degenerar na necessidade de possuir a verdade absoluta que alem de tentar uma ayentura amorosa com a rapariga que descebrira a pra se proluta, que allm de Geunde Gounod depressa esquece as suas chises de fe dos printelros episodios orquestrais e converte-se num galā que faz a corte a Margarida com muito acerto, a abandona sem explicaçāo e pretende recuperá-la quando ela já aprendeu a liçāo. Esta aparente simplicidade da personagem deve ser moldada pela interpretaçăo do tenor lírico que, sobretudo no dueto do terceiro ato, tem de imprimir ênfase a cada uma das suas intervençōes para revelar as contradiçōes entre a sua ânsia de conhecimento intelectual e os seus impulsos amorosos. ${ }^{23}$

O comentário refere-se ao primeiro encontro de Fausto com Margarida depois de enviado o presente tentador (as jóias), quando se dá a primeira investida mais ousada do galã que, entretanto, ainda hesita. Tanto é que ele vai embora sem seduzi-la, atendendo ao seu pedido, sendo depois repreendido por Mefistófeles.

O mesmo ocorre com Margarida; segundo o especialista citado. A simplificação que a ópera realiza do texto de Goethe seria compensada em parte pela nova unidade que se criaria por meio de uma utilização competente da música, da orquestra e das vozes. Isso é exemplificado com o canto de Margarida, "sempre lírico e brilhante". Confia-se aqui na interpretação da soprano que constrói os matizes que o texto não pode oferecer, como na célebre área das jóias, que expressa tão bem, mais na música e nos gestos previstos para a intérprete do que na letra, a ambigũidade dessa personagem, entre vítima e culpada, entre ingênua e simples, de um lado, vaidosa e interesseira, de outro. O caráter emotivo e indeciso de Margarida também é sugerido. Sua coqueterie, bem explorada, e a introdução do espelho no fundo da caixinha do presente armado por Mefistófeles brincam com a idéia do ser e não ser: "És tu Margarida, és tu? ... Nāo! Não! Já não és tu".

22 "A moi les plaisirs, /les jeunes maitresses! /à moi les caresses, /à moi leurs desirs! /à moi l'energie Ides instincts puissants, fet la folle orgie /du coeur et des sens! /Ardente jeunesse, /à moi tes desirs /à moi ton ivresse, /à moi tes plaisirs /a moi ton ivressel a moi tes plaisirs... IA moi les plaisirs, Mes jeunes maitresses! /à moi leurs caresses, /a moi l'energie /des instincts puissants let la folle orgie /du cocur et des sens. /Ardente jeunesse /a moi ton ivresse la moi tes plaisirs /à moi ton ivresse /a moi tes plaisirs /a moi ton ivresse fa moi tes plaisirs // Mefisto:à toi les plaisirs, hes jeunes maitresses! /à toi leurs caresses, là toi leurs desirs/a toi lenergie /des instincts puissants /et la folle orgie/ du coeur et des sens, /a toi la jeunesse, fa toi ses desirs /a toi son ivresse /a toi ses plaisirs /a toi son ivressel a toi ses plaisirs. "(p. 63-4)

${ }^{2}$ Introduçảo ao libreto da opera já citado, p. 27.
Orquestra e vozes introduzem efeitos dramáticos que é preciso levar em conta no diálogo entre o texto e a música. O tratamento do coro é delicado, policromo e vibrante, como no coro dos soldados, fragmento de outra ópera nāo estreada que aí é introduzido, seguindo a tradiçāo musical das marchas militares, agora assimiladas já sem a força revolucionária e tornadas espetáculo de grande efeito em cena.

A ópera é eminentemente urbana, por isso nela o ruralismo do texto de Goethe se atenua e os movimentos de massa se fortalecem, porque são imprescindíveis ao gênero.

Freqüentemente, a música introduz contrapontos, como a ânsia de absoluto na introduçāo, responsável pelos aspectos sombrios do canto de Fausto, confrontada ao coro feliz das mulheres e homens indo para o trabalho. Todos os motivos principais do texto de Goethe estāo aí: a noite, a natureza, o criador, o livro, o saber, a manhã, o trabalho, a taça com o veneno.

No terceiro ato, a cavatina "Salut, demeure chaste et pure!" é uma das passagens mais célebres da ópera, marcando o início do processo de seduçāo de Margarida também de uma ambigüidade que desmente a unidimensionalidade do Fausto galã e don Juan. Os estudiosos destacam aí a simplicidade melódica, o trabalho das cordas, do violino solista e o dó de peito, tão apreciado pelos conhecedores de ópera. Há na cavatina, a um só tempo, ironia e pureza. O canto diz a Margarida: "fique casta e pura"; mas Fausto quer seduzi-la. Há aí também a idealização da pobreza, a figura da mulher pura e pobre, intimamente ligada à natureza, figura típica do gênero bucólico de que a ópera, eminentemente urbana, se serve para aumentar o pathos.

Finalmente, não podemos nos esquecer do papel de Marta e o jogo de contrastes no quarteto formado por ela, Mefistófeles, Margarida e Fausto, no qual se cruzam a ingenuidade desses com a malícia daqueles. Utiliza-se aqui um esquema dos quartetos bufos tradicionais, contrapondo sentimentos por técnicas expressivas diferentes. ${ }^{24}$

Para invocar Satã e para ajudar na sedução, apela-se para as forças da natureza: da noite, das flores... No jogo do bem-me-quer, mal-me-quer, o destino é selado pela flor. E o momento da seduçāo aparece precedido por uma verdadeira orgia orquestral. Já no momento de abandono a música se faz quase onomatopéia das ânsias e soluços de Margarida. No final, a luta entre os anjos e os demônios se expressa musicalmente num dramático diálogo do bem e do mal.

$\mathrm{O} V$ ato é a famosa noite de Walpurgis. Temos aí o canto das bruxas. O mal se revelando no coro e no canto de Mefisto. No final, a ascensão de Margarida, expressa pelo coro celeste, contrasta com a fuga de Mefisto e a prostração, de joelhos, de um Fausto desesperado.

Assim, deixando a filosofia para o alemāo, o compositor francês parece preferir contar uma história de amor, recriando, como pode, com a ajuda dos recursos musicais próprios da ópera, senāo algumas das significaçōes, pelo menos algumas

${ }^{24}$ José Avinoa, "Fausto em português", op. cit., p. 99 
das sensações mais transcendentes do drama goethiano. Portanto, nāo nos devemos deixar enganar pela aparente superficialidade da ópera, pois no confronto que se estabelece aí entre o livreto e a música, pode haver alguns mistérios que, ao mesmo tempo, se velam e se desvelam ao ouvinte sensível, como o da identificaçāo do próprio Gounod, o padre músico, com Fausto, o sábio insaciável. É o que nos explica Sergio Segalini:

En ecoutant cette oeuvre, on réalise parfaitement que Gounod et Faust sont un seul et même personnage, et un jeu de miroir s'établit entre le vieux chercheur, assoiffé de jeunesse et divresse, de désir et de plaisir, en quête d'un équilibre impossible, et le composittur [...] A travers les excès de l'écriture, Gounod cache parfois sa pudeur, sa veulerie et se livre. "Faust" devient alors l'opéra qui resume toute la camière de Gounod ${ }^{25}$

\section{O poema}

"En mi corta experiencia de narrador he comprobado que saber cómo habla un personaje es saber quien es, que una una entonación, una voz, una sintaxis peculiar, es haber descubierto un destino." (Jorge Luis Borges)

O poema de Estanislao del Campo também se fixa apenas na primeira parte do poema de Goethe, filtrado como é pela ópera, mas se compararmos seus principais momentos com o texto de Goethe e com o livreto de Jules Barbier e Michel Carré, constataremos ter havido acréscimos que, embora aparentemente minimos, apontam para dimensōes sugeridas na ópera apenas por meio da música de Gounod.

Estanislao del Campo nasceu em Buenos Aires em 1834. Era filho de coronel, chefe do Estado Maior do general Lavalle. Estudou na Academia Porteña, onde aprendeu inglês. Em 1853, participou da defesa de Buenos Aires, contra Hilario Lagos. Teve um posto na alfândega e foi secretário da câmara de deputados. Combateu em Cepeda e Pavón, vindo a tornar-se deputado nacional pela província de Buenos Aire. Em 1874 participou da Batalha de La Verde e, na campanha, adoeceu gravemente da laringe, doença que carregou até morrer.

Poeta gauchesco, frequientou também a poesia dita culta. ${ }^{26} \mathrm{Na}$ poesia gauchesca, como era próprio do gênero e como seu amigo Ascasubi (que usava a poesia como arma contra o caudilho Rosas), defendeu temas políticos, colocando-se do lado da causa de Buenos Aires contra as provincias. Ideologicamente dava prosseguimento também a Sarmiento, atacando a barbárie caudilhesca em nome de um projeto ilustrado de civilizaçāo. De como o seu Fausto, aparentemente uma simples brin-

25 "Le charme ambigũ de Faust", in Folheto que acompanha o CD FAUST, Gounod, Kiri Te Kanawa-Francisco Araiza, Evgeny Nesterenko, Symphonie-Orchester x Chor des Bayerischen Rundfunks, dir. Sir Colin Davis, Philips, p. 39

${ }^{26}$ Pode-se argumentar que a poesia gauchesca é também culta, mas, embora reconhecendo que ela procede de autores cultos e citadinos, preferimos considerá-la, na esteira de Angel Rama, uma espécie de gênero híbrido, entre o culto e o popular, entre o escrito e o oral. cadeira, acaba problematizando essa oposição e fugindo ao padrão ideológico da gauchesca, tanto na sua vertente federalista quanto na unitária, falaremos depois de nos determos um pouco no poema.

Como já dissemos, narram-se aí as impressōes de um gaúcho, Anastásio el Pollo, a outro gaúcho, Laguna, diante do que o primeiro viu no teatro Colón - a representaçāo da ópera de Gounod que el Pollo traduz em termos próprios ao seu Universo e do seu companheiro. Esse, muito atento, volta e meia interfere na narraçāo com comentários e exclamaçōes.

Se compararmos o poema de Estanislao com o poema de Goethe, verificaremos que aquele, como o livreto da ópera, também opera uma grande condensação da ação dramática e uma simplificação geral da obra alemā. Mas há diferenças a assinalar.

O poema se faz como uma narrativa enquadrada. Começa com o encontro dos dois gaúchos em pleno pampa. A primeira cena é dominada pela presença dos cavalos, orgulho do gaúcho e espécie de duplicação da amizade simples, direta e sólida que existe entre os dois homens. A partir de uma invocação ao demônio por parte de Laguna, expressāo trivial na fala do gaúcho, el Pollo começa a narrar que viu o dito cujo e comprovou que ele existe, aconselhando seu amigo a nāo invocálo em vão. O outro fica curioso e Pollo narra como o diabo apareceu a Fausto que, apaixonado por uma ruiva, acabou cedendo à tentaçāo e aceitando vender sua alma em troca da juventude e do amor dessa moça. Eis como se narra com o auxílio de uma comparação agauchada a cena da metamorfose pós-pacto:

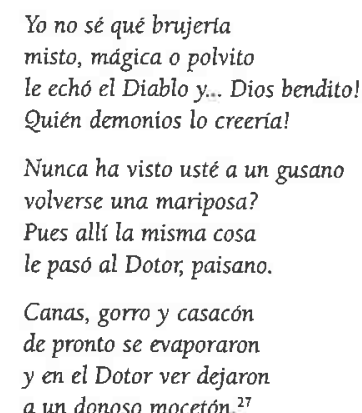

Narrados o pacto e a metamorfose de Fausto, faz-se uma pausa para observar o comportamento dos cavalos, bebendo água juntinhos, para tomar um trago e para um excurso inesperado e aparentemente sem funçāo sobre o mar que analisaremos adiante.

Daí para a frente, Anastasio vai contando a mesma histónia da ópera, adaptando personagens e cenários ao seu mundo. Assim é que Margarida vira a rancheirinha ruiva e Valentim, soldado da Guerra do Paraguai, entre outras adaptaçōes que aproxi-

${ }^{27}$ A edição utilizada aqui é a da Biblioteca Ayacucho, Poesia Gauchesca, prólogo de Ángel Rama, selección, notas y cronologia de Jorge B. Rivera, Caracas (1977, p. 158). 
mam o drama fáustico da realidade do gaúcho, de modo semelhante ao que Gounod havia feito em relação ao mundo da burguesia parisiense da época romântica.

A narrativa de Anastasio condensa mais ainda o enredo, respeitando a divisão em cinco partes, realizada pelos libretistas da ópera. Mas a cada final de ato cai o pano e o diálogo volta a se deter na paisagem real ou imaginada pelo gaúcho ou parte para uma digressāo em que Pollo, respondendo às reaçōes de Laguna, discorre sobre temas conexos ao núcleo da ópera, como o tema do amor, responsável por um dos mais belos excursos do poema.

Se na ópera o que não se tomou de Goethe foi de certa forma compensado pela elaboração musical, aqui a anedota ganha dimensāo lírica, mítica e filosófica sobretudo pela inclusão desses excursos (sobre o mar, sobre o amor, sobre o amanhecer, a noite e a mulher) que passamos a comentar.

\section{Sobre o mar}

Localizado entre a cena do pacto e a cena da taverna, temos um longo trecho, de doze estrofes, que canta o mar, começando assim:

- Sabe que es linda la mar?

- a viera de mañanita

cuando a gatas la puntita

del sol comienza a asomar!

O gaúcho, na cidade de Buenos Aires, descobre, além do teatro, o mar, uma natureza outra em relação ao pampa de onde provém. Associado ao pampa, o mar é tradicionalmente um topos na literatura argentina, desde os viajantes, passando por Sarmiento e chegando aos ficcionistas da atualidade, assim como, no Brasil, aparece associado ao sertão, um deserto visto como mar. Laura Fabiana Cilento, estudando as tensões entre o campo e a cidade no romance argentino mais recente, comenta a presença incessante dessa metáfora que, se no início se teria prestado à descriçāo, acaba com o tempo servindo à representaçāo de uma "realidade transfigurada" ${ }^{28}$ Walnice Nogueira Galvāo, no belo ensaio intitulado "metáforas náuticas", ${ }^{29}$ analisa a presença do mar na obra de Guimarāes Rosa, como topos já tradicional no Brasil (de Manoel Antonio de Almeida e Machado de Assis a Euclides da Cunha, Graciliano Ramos e Glauber Rocha) para exprimir o seu oposto: "no lugar indevido, porque o mais seco: no sertāo" 30

Podemos ler nesse excurso sobre o mar no texto de Estanislao del Campo, para além da simples descrição, o caráter simbólico mais amplo dessa "descoberta" da

28 “Tensiones campo/ciudad en la novela (1970-1993)", in Lateinamerika-Studien 36, Universitāt Erlangen-Nürnberg, Zentralinstitut (06), Sektion Lateinamerika, número sobre Culturas del Río de la Plata (1973-1995), transgresión y intercambio, ed. Roland Spiller, Vervuert Verlag, Frankfurt am Main, 1995, p. 116.

${ }^{29}$ Walnice Nogueira Galvāo, Desconversa, Rio de Janeiro, Ed. da UFRJ, 1998, p. 115-28.

${ }^{30} \mathrm{Idem}$, ibidem, p. 115. sua personagem. A realidade é, assim, transfigurada, fundindo-se com a fantasia nesse mar que acaba superpondo-se ao pampa sumindo no horizonte, e que pode também ser lido como figuraçāo do destino para o gaúcho fatalista. Funde-se aî também uma visão pagã do mar, deus irado, com uma visāo cristā que o submete ao comando do Senhor, aproximando muito essa parte do poema ao canto dos arcanjos no prólogo de Goethe, completamente esquecido pelo livreto da ópera. Não faltam aí, ao lado dos peixes, a prata e a luz, louvados pelos arcanjos como obra do grande criador. Dessa forma, passa-se, da simples anedota burlesca, ao sentimento do sublime e do mistério na vida do homem e da natureza, revelando a sabedoria existente na religiosidade difusa do homem pobre do pampa.

O excurso do mar, tendo uma unidade nele mesmo, entronca-se também na narrativa, não apenas porque retoma o seu movimento, da serenidade à tempestade e à nova calma, mimetizando o processo da própria vida humana, como porque, aludindo indiretamente ao prólogo de Goethe, encena o diálogo intertextual que deu origem ao poema de Estanislao del Campo.

\section{Sobre o amor}

Situado entre a cena do baile, onde se dá o primeiro encontro de Fausto com a ruiva, e a cena bucólica da quinta, onde se dá o segundo, o excurso do amor é um momento de lirismo em que Anastasio el Pollo parece querer compreender o drama de Fausto e, de certo modo, justificá-lo, como vítima de cupido. São dezenove estrofes iniciadas por um diálogo entre el Pollo e Don Laguna que, gaúcho mais estereotipado, se mostra "durāo" em rẻlaçāo às mulheres e desdenha o amor:
$Y$ digo pobre Dotor,
porque pienso, Don Laguna,
que no hay desgracia ninguna
como un desdichao amor.
- Puede ser; pero amigaso,
yo en las cuartas no me enriedo
$y$, en un lance en que no puedo.
hago de mi alma un cedaso.
Por hembras yo no me pierdo:
la que me empaca su amor
pasa por el cernidor.
Y...si te vi, no me acuerdo.
Lo demás es calentarse
el mate al divino ñudo.
- Feliz quien tenga ese escudo
con qué poder rejuardarse!

Anastasio el Pollo, porém, argumenta com as magias do amor. Esse ganha entāo uma dimensāo cósmica que acentua a sua força arrasadora. Na ausência da amada, amplifica-se sua presença no vento, no sono, na lua e nas estrelas. E essa ausência-presente é ao mesmo tempo gozo e sofrimento para o apaixonado. Entre- 
tanto, simetricamente, na sua presença, se ela o olha, provoca um tropel na cabeça e espinhos no coração. Ao contrário, se não o olha, é vista como ingrata e a dor do abandono deixa um sulco no coração.

O mais curioso aqui é que se inverte um topos do gaúcho macho, indiferente aos males do amor, para quem é fraqueza chorar por uma mulher ou entregar-se incondicionalmente à paixão. ${ }^{31}$ A primeira observaçāo de Laguna traz esse tópico à baila. Mas ele não pode ficar indiferente às palavras do amigo, acabando por concordar com a força mágica desse sentimento, antes de reclamar mais uma vez impaciente pela continuidade da história interrompida:

- Gueno,amigo: ast será

pero me ha sentao el cuento...

- Qué quiere! Es un sentimiento.

tiene razón; alla va: (p. 167)

\section{Sobre o amanhecer}

O terceiro excurso é a descriçāo de um amanhecer no rancho, colocado entre o momento em que a "ña Julana" se debruça à janela, vendo a manhã nascer e pensando em Fausto e a cena seguinte em que ela, finalmente, se entregará ao amante, quando esse, incitado pelo diabo, faz a última investida. O momento que antecede o encontro amoroso é idílico e o cenário também. A natureza, cúmplice, parece conspirar pelos amantes, como em qualquer drama romântico que se preze; mas a luz da manhā, o sol que surge, é também fogo e paixāo:

\section{No ha visto uste de un yesquero \\ loca una chispa salir, \\ como dos varas seguir \\ $y$ de ahi perderse, aparcero? \\ Pues de ese modo, cuñado \\ caminaban las estrellas \\ a morir, sin quedar de ellas \\ ni un triste rastro borrao.} dílica:

Diminutivos, aumentativos e comparaçōes concorrem aí para criar a atmosfera

$$
\begin{aligned}
& \text { En los verdes arbolitos } \\
& \text { gotas de cristal brillaban, } \\
& \text { y al suelo se descolgaban }
\end{aligned}
$$

cantando los pajaritos.

${ }^{31}$ O que nāo signifique que se ignorem os gaúchos chorōes da gauchesca, como é o caso do próprio Martin Fierro, mas Don Laguna, aqui, marca a encenada indiferença desses hornen frequientemente representados como mais apegados aos seus cavalos do que a suas mulheres.
A natureza se anima pela metáfora que traduz sensaçōes e sentimentos no código do gaúcho. Quando comentara a transformaçāo de Fausto, de velho em moço, o mesmo recurso fora utilizado. Vimos que Pollo utilizou aí a imagem da lesma que se transforma em borboleta, procurando, por meio dessa imagem, concretizar a cena para o amigo Laguna, trazendo-a mais perto do seu universo. Aqui é o céu que muda de cor como um cavalo que muda de pêlo. A comparaçāo é tão bizarra que Laguna a estranha, mas a naturalidade com que Pollo a justifica acaba sendo convincente para ele e para o leitor:

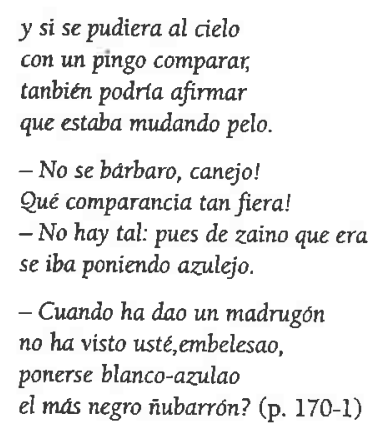

Esse excurso, como já foi dito, antecede a cena de sedução. Tudo aí é ainda claridade e beleza, porém a mariposa chupando o botāo de rosa antecipa a imagem da morte, associada ao mesmo símbolo no excurso sobre a mulher, analisado mais adiante.

\section{Sobre o anoitecer}

Antes disso, temos a simétrica descriçāo de um anoitecer, com toda a carga fúnebre, digna da desgraça que aguarda a jovem. Tal excurso vem entre a cena da Igreja, de onde ela é expulsa pelo diabo, e a cena da morte de seu irmão, Valentin, e tem sete estrofes que começam assim:

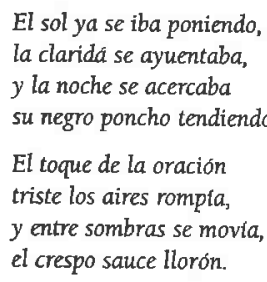

O negro poncho da noite é antecipador do destino sinistro que aguarda a moça, agora abandonada por todos, corrida da igreja e prestes a perder o irmāo pelas māos do diabo e de Fausto. A árvore escolhida para compor a paisagem agora é o salso chorão e o pássaro agourento, a coruja, também simbolo da sabedoria e do destino. 


\section{Sobre a mulher}

Mas o excurso mais surpreendente, tratando-se da gauchesca, em geral tão machista é o que comenta a sina da mulher e a compara com o melhor destino dos homens. O momento é para tirar a moral da história, por meio da filosofia popular renovada e assim enunciada:

$$
\begin{aligned}
& \text { - Ainsi es el mundo, amigaso! } \\
& \text { nada dura, Don Laguna, } \\
& \text { hoy nos re la fortuna, } \\
& \text { mañana nos da un guascaso. } \\
& \text { Las hembras, en mi opinión } \\
& \text { train un destino más fiero, } \\
& \text { y si quierc, compañero, } \\
& \text { le haré una comparación. }
\end{aligned}
$$

A comparação é desenvolvida narrativamente nas oito estrofes seguintes, comparação entre a história de uma moça e a história de uma flor, violentadas respectivamente pelo vento e pelos homens. Aí se juntam excurso e discurso, pois a flor, agredida pelo vento, pela mariposa e pelo beija flor, volta como cadáver, antecipando a morte da jovem vítima do Dr. Fausto. Mas antes já havia acontecido um comentário sobre a sorte das mulheres, quando se narrava o seu abandono. É também o momento em que se relativiza o machismo, já que Anastasio nāo se envergonha de confessar que chorou vendo o sofrimento da moça:

\section{La pobre dentró a quejarse}

tan amargamente alli,

que yo a mis ojos senti

dos lágrimas asomarse. (p. 171)

E, mais uma vez Laguna faz o papel do machão tradicional a quem é proibido chorar:

-Qué vergüenza! (p. 171)

Mas Pollo aproveita para lastimar o sofrimento das mulheres, ante o que nenhum homem pode deixar de comover-se. Faz parte da retórica de Pollo para comover e convencer seu interlocutor inseri-lo como personagem no drama da moçaflor. O efeito nāo se faz esperar: desvenda-se, assim, o outro lado do gaúcho e do próprio Laguna que, no final, chorará também:

- Puede ser:

pero, amigaso, confiese

que a usté también lo enternece

el llanto de una mujer.

Cuando a usté un hombre lo ofiende,

ya, sin mirar para atrás. pela el flamenco $y$ sas! tras!

dos puñaladas le priende.

$\cdots$

Aura, confiese, cuñao

que el corazón más calludo,

que el corazon mas calludo,

yel gaucho mas entrand

- Sabe que me ha sacudido

de lo lindo el corazón?

vea si no el lagrimón

que al otrlo se me ha salido.

- Oiganle! (p. 173-4)

Mais adiante, pouco antes do final do poema e logo depois de encerrada a narraçāo de Pollo, o pranto de Laguna volta, embora disfarçado:

\section{Cayo el lienzo finalmente \\ $y$ ahi tiene el cuento contao. \\ - Prieste el pañuelo, cuñao \\ me está sudando la frente. (p. 182)}

Assim, se levarmos em conta os excursos e as reaçōes de Laguna, veremos que a dimensão transcendental que, na ópera, é conseguida pela música, aqui se corporifica em metáforas que, nāo por serem própriass ao mundo do gaúcho, deixam de expressar os mistérios e sutilezas dos sentimentos e das paixões humanas, bem como uma reflexão do gaúcho fatalista sobre a luta do homem livre contra forças que nāo pode entender nem dominar.

Seguindo a convençāo da gauchesca, une-se o senso da natureza à capacidade de criar imagens sedutoras, uma entonaçăo que passa da oralidade à letra a uma sintaxe peculiar e se constroem personagens com voz tão própria que perfilam tipos e destinos ao mesmo tempo individuais e gerais. A epigrafe de Borges aqui utilizada aplica-se, assim, inteiramente, a Pollo e Laguna. Mas há mais, o tom. burlesco não impede que leiamos no texto a ternura e o respeito pelos personagens. Tem razāo novamente Borges: no caso do poema de Estanislao, a "broma" se junta à "amizade" e isso dá uma dimensão extremamente humana e concreta ao gaúcho e ao seu mundo, a partir do qual a cidade estranhada é, agora, a seu modo, assimilada. Retoma-se na ida de Pollo à ópera e na narrativa que faz ao companheiro dessa verdadeira aventura extraordinária o humor de cenas antológicas próprias à gauchesca, como a do gaúcho indo às festas mayas, num poema famoso de Bartolomé Hidalgo. Mas, ao mesmo tempo, supera-se o exótico e pitoresco injetando na dupla uma voz e um imaginário próprios, aliados à simplicidade e à delicadeza de um sentimento como a amizade. Rompem-se, assim, estereótipos como o do gaúcho macho que. faz até chorar o gaúcho mais empedemido, quando o amigo argumenta com sensibilidade, respeito e inteligência.

Ainda retomando Borges, podemos perceber que o poema demonstra uma "notável sensibilidade visual" e uma "propensão ao humorismo" nada agressivo ou 
amargo, um humorismo cujo "manancial é a felicidade". A combinação desses elementos com aquilo que Borges chama "a infinita e pacífica exaltação da amizade" acaba trazendo para esse tema uma significação histórica e ideológica à primeira vista nada evidente. É o que procuraremos investigar agora, por meio de um rápido desvio pela gauchesca como gênero e pela caracterização do momento histórico em que Goethe entra no mundo hispânico e, mais especificamente, na narraçāo de um gaúcho.

\section{O gênero: a gauchesca como tradiçāo e convenção}

A gauchesca é um gênero que se constituiu por uma evoluçāo lenta e particular, assimilando parte de uma tradição oral à invenção convencional de autores letrados e citadinos. Com a invençāo de um gênero, inventa-se também um público novo. E, com o público, inventa-se o escritor. Um tipo novo, que não adentraria facilmente nas academias de Letras pautadas pelos padrōes europeus. Trata-se de um movimento em que a ideologia está clara, de uma poesia de combate.

A gauchesca percorreu três etapas, uma neoclássica, outra romântica, e outra realista. Respectivamente, por volta de 1810,1850 e 1870 . Hidalgo é visto pela crítica como neoclássico; Ascasubi, romântico; Hernández, realista. Estanislao del Campo parece estar entre todas essas tendências, fundindo-as em seu Fausto por meio da paródia construtiva, irreverente mas simpática.

Borges insiste no caráter convencional dessa poesia, contrariando a hipótese da sua origem popular e atacando a crítica verista e positivista que buscava veracidade na imagem do gaúcho veiculada por esses textos:

La poesia gauchesca, desde Bartolomé Hidalgo hasta José Hemández, se funda en una convención que casi no lo es, a fuerza de ser espontánea. Presupone un cantor gaucho, un cantor que a diferencia de los payadores genuinos, maneja deliberadamente el lenguaje oral de los gauchos y aprovecha los rasgos diferenciales de este lenguaje, opuestos al urbano. ${ }^{32}$

Para Borges, o homem urbano teria achado no campo

um espetáculo que era o bastante curioso para ser memorável e o bastante afim para ser ínumo. O campo com suas grandes distâncias, seus bárbaros rebanhos, com seus perigos elementares, com seu sabor homérico, seria na memória uma experiência de liberdade e plenitude. ${ }^{39}$

Mas com o Fausto agauchado acaba-se operando uma inversăo: em vez do campo visto pela cidade, ou pelos olhos de um narrador que nos apresenta o caipira deslocado e maladroît fora do seu hábitat, vemos a cidade sob os olhos do paisano. É a esse outro lado da tradição, iniciada talvez pela visita do gaúcho de Hidalgo às festas mayas em Buenos Aires que o Fausto parodicamente nos remete.

\footnotetext{
${ }_{33}^{32}$ Jorge Luis Borges, op. cit., p. 10.
}

${ }^{33} \mathrm{Idem}, \mathrm{ibidem}, \mathrm{p}$. 10, tradução minha.
Concordando com a visāo de Borges, Ángel Rama chama atenção para a gauchesca como projeto de fazer literatura nacional com base na imitaçāo sistemática da linguagem e estilo dos gaúchos. Não se tratava, portanto, de criaçōes espontâneas do povo cantor, embora possamos admitir com Josephina Ludmer que há fontes populares de que se alimenta a gauchesca, como os cielitos. ${ }^{34}$

Ángel Rama também discute a versāo meio romântica de que esses autores seriam semi-alfabetizados, para mostrar que eram parte da elite do país, ocupando cargos de direçāo em instituiçōes públicas e postos de destaque no exército.

Houve toda uma evoluçāo ideológica na gauchesca: Hidalgo acredita ainda numa pátria una, logo após a independência. $O$ inimigo é o espanhol e ele fala em nome do povo como um todo. Depois, com as lutas entre as várias facçōes nacionais, o inimigo é interno e, no tempo de Ascazubi, já se toma partido, no caso deste, contra Rosas e as provincias e a favor de Buenos Aires, da civilização contra a barbárie. No terceiro periodo, não há mais guerras, tendo sido Rosas derrotado, mas faz-se a conquista do pampa, o cercamento dos campos, aplicando-se códigos severos como a "lei dos vagos". A Argentina moderniza-se, a economia exportadora exige a racionalizaçāo a ferro e fogo. Disso se queixa amargamente, sofrendo as consequêencias, o valente Martin Fierro, de José Hernández.

A gauchesca procura estabelecer uma ponte entre a poesia do povo e a mente culta da classe superior, segundo Ángel Rama. Literatura fronteiriça, entre a culta e a popular.

A crítica do século XIX ignorou esse tipo de produção que não se propunha a concorrer com a considerada alta literatura. No entanto, para Rama, ela se integrava às incipientes literaturas nacionais do Prata. Só no século XX houve a valorizaçāo dessa poesia que se destacava, pela originalidade, da poesia europeizada do mesmo período. A crítica começa a perceber então que, feita a independência política, é a poesia gauchesca que tenta continuá-la na independência lingūística e cultural, constituindo um gênero de fronteira, com uma língua de fronteira,

A poesia gauchesca realiza aquela espécie de $T$, que Roberto Schwarz lê em Grande sertão: veredas e que eu mesma identifiquei em Simões Lopes Neto, pela fusão dos gêneros lírico, épico e dramático. Narrativa "inserta em diálogo", na feliz expressão de Schwarz. ${ }^{35}$ Tal narrativa "canta um argumento", como diria Martin

${ }^{34}$ Os cielitos costumam ser considerados pelos estudiosos como formas de cantos do folclore europeu transplantadas para o Prata e adaptadas aos poemas patrióticos a partir da Independência em 1810. Para uma visão equilibrada da gauchesca entre o popular, oral e o escrito, citadino e culto bem como para as ambigưidades da letra e da lei na invenção da pátria, latentes nesse sistema poétiCo, ver Josefina Ludmer, El género gauchesco. Un tratado sobre la patria, Buenos Aires, Sudamericana 1988. Ver, também, Ángel Rama, Los gauchopoliticos rioplatenses, Buenos Aires, Jorge Álvarez, 1968 Ver, ainda, Eduardo Romano, "Originalidad americana de la poesía gauchesca. Su vinculación con los caudillos federales rioplatenses", in Ana Pizarro (Org) América Latina, palavra literatura coulta , São Paulo e Campinas, Memorial da América latina e Editora da Unicamp 1994 vatura c cultu-

${ }^{35}$ Ver Roberto Schwarz, A serein e o desconfiado, Rio de Jeneiro, Paz e Terra 1965; e Ligia Chiappini, No entretanto dos tempos: literatura e história em João Simôes Lopes Neto, São Paulo, Martins Fontes, 1988. 
Fierro, e o papel do receptor é mais o de fazer perguntas. Embora aqui Laguna também fale (ao contrário dos interlocutores de Riobaldo e de Blau Nunes), a fala predominante é a de Pollo, num quase monólogo que incorpora o diălogo para além do que o interlocutor explicitamente diz. Por isso, nessa fala inserta em diálogo, importa talvez mais a entoaçāo que o sentido. O trabalho estilístico e propriamente literário, como nos exemplos brasileiros, é de insuflar a oralidade na letra e, para ler, há que ouvir. As personagens, ao mesmo tempo, cantam, narram e representam, traduzindo, assim, um pouco da ópera no outro sisterna ou gênero. Rama diz isso de outro modo ao notar que a voz dos poetas gauchescos, poetas da cidade e distanciados das camadas pobres, chega a elas pela música dos seus poemas.

Já víamos que havia uma vertente engraçada, de "broma" do gaúcho, na tradição da gauchesca. Contra essa insurge-se explicitamente, e com razão, José Hernández, pois o gaúcho saía desmoralizado de cenas em que era apresentado como um matuto na cidade. Pois também no tocante ao humor, Del Campo retoma a tradição, subvertendo-a, já que o gaúcho é tratado de modo simpático e respeitoso.

Rama insiste em que a gauchesca é um sistema literário rígido e estruturado. Com Hidalgo, cria-se um gênero e um estilo adequado a esse gênero, com um repertório de temas e formas artísticas não-canônicos. Levando em conta isso, podemos pensar que Estanislao del Campo, em Fausto, faz-se duplamente hibrido, na medida em que reafirma e ao mesmo tempo contraria o modelo, ou melhor, as normas do gênero, introduzindo aí um tema atípico, fazendo um gaúcho defender as mulheres e o amor, e chegando a confessar que macho também por elas pode chorar.

\section{O gaúcho na ópera e Goethe no pampa}

Eduardo Romano, no texto citado, aponta a originalidade americana da poesia gauchesca e a vinculação dessa aos caudilhos federais rioplatenses. O lado de Estanislao parece menos nítido, pelo menos no poema em questão, com um tema aparentemente frivolo e distante do mundo do gaúcho, inspirado na ópera, mas também, certamente, na leitura de Goethe. Mas por que essa idéia? Haveria algo a para além ou por trás da simples brincadeira? O quê e para quê? Para dizer o quê? Ensinar divertindo? Até que ponto se trata ainda de um projeto ilustrado, afinado com a ideologia dos unitários de Buenos Aires contra os federalistas caudilhos? Para tentar responder será preciso fazer mais um pequeno desvio, dessa vez pela significação que pode ter a entrada de Goethe no mundo hispânico.

Goethe entrou na Espanha e na Hispano-América por intermédio da França. A literatura clássica alemã, especialmente Goethe, era lida na França pela mediação de olhos franceses, como os de Madame de Stäel. Na Espanha, via França, chegava já um Goethe esvaziado da sua carga metafísica e mística para aguar-se num romantismo típico da ópera oitocentista, apesar de que, assim mesmo, entrava como signo de modernidade, de abertura do espírito contra os dogmas, de liberdade e valorizaçāo do indivíduo racional. Levando esses dados em consideraçāo, fica mais claro ainda o papel da ópera de Gounod numa Argentina que se moderniza e precisa apoiar-se na Aufklārung contra a "barbárie do caudilhismo".

Alguns fatos da história da Argentina talvez possam ajudar a compreender as condiçōes de produçāo do Fausto de Estanislao. O poema é escrito em plena Guerra do Paraguai, à qual, aliás, alude duas vezes. Essa guerra exprime bem o momento em que, na chamada luta das duas Argentinas (a das províncias e a de Buenos Aires) a segunda se impõs, com a vitónia dos interesses mercantis e financeiros contra o dos fazendeiros. Antes já se havia dado o fim da ditadura de Rosas, 1852 e, em 1862, a nova unificaçāo do país. O poema é escrito na era de Mitre, com o país integrado. Embora as províncias ainda detenham o maior número de habitantes, um terço desses vivem nas grandes cidades. Está tudo se preparando para a chegada dos imigrantes e a morte dos gaúchos que renascerão apenas na gauchesca. Os porteños que sempre tiveram tendência separatista só acalmariam pela consolidaçāo, em 80, do papel de Buenos Aires como capital toda poderosa de uma nova Argentina, cosmopolita e europeizada. ${ }^{36}$ Mas na época da publicaçāo do poema o jogo de forças já está praticamente definido. Clara Rey de Guido assim define o período:

Desde el gobiemo de Mitre (1862-1868) en Buenos Aires, lo urbano y lo elitista se imponen sobre lo nural y popular. Las protestas y rebeliones se suceden debido a la forma como los gobiemos impulsan la modernización: la distribución de las tierras para los extranjeros desconociendo los derechos de los nativos, la mentalidad distinta de los inmigrantes rente a la criolla, la industrialización el alambrado de los campos, entre tantas otras razones, provocan resentimientos en los locales, lo cual muchas veces degenera en bandoleirismo y banditismo. Los sectores marginados por la nueva mano de obra se convierten en xenófobos, pero inconscientemente van asimilando nuevas pautes traidas por los inmigrantes. Es el lado oscuro de la modernización impucsta desde una metrópoli que cada vez estrecha mas los vinculos intelectuales, sociales, económicos y financieros menopoli que Estados Unidos. Factores sociales, ideologicos, econónicos, politicos y culturales condujeropa y transformación de las ciuda des capitales curopeas (Paris yuerto de Montevideo y Bucnos Aires. La comunicación con las grandes capitales curopeas (Paris y Londres) era permanente debido a los bancos y casas comerciales francesas $e$ inglesas. De ahí el intento de reproducir modelos tanto en el modo de vida como en las edificaciones, en la economia, en la literatura. ${ }^{37}$

Colocando o gaúcho na ópera, a traduzir para o seu mundo a célebre história de seduçāo, abandono, insatisfação com a velhice e venda da alma em troca de juventude e amor, Estanislao está talvez apontando para uma síntese desejável e nunca conseguida, entre Buenos Aires e as provincias. Destacando a simplicidade do homem pobre do pampa, sua lealdade e amizade, contra a guerra e a violência, pōe em relevo o lado civilizado do gaúcho e, ao mesmo tempo, relativiza a importância do refinamento citadino de uma Buenos Aires que se quer mais francesa e inglesa que americana e que volta as costas ao pampa, sem perceber quäo perto

${ }^{36}$ José Maria Rosa, Historia Argentina, v. 6 e 7; Felix Lima, Historia Integral de la Argentina: Planeta. H. S. Ferns, La Argentina, Buenos Aires, Editorial Sudamericana

${ }^{37}$ "La literatura popular rioplatense en el periodo de la modernización", in Ana Pizarro (Org.) América Latina, palavra, literatura e cultura, op. cit., p. 388-9. 
dele está. Aponta-se, assim, para um modelo civilizatório, que estaria mais para Alencar do que para Sarmiento, embora aqui o tom de brincadeira já implique um afastamento que talvez aponte para o irrealizável. De todo o modo, toma-se distância, pelo riso e pelo tratamento simpático e sensível dado ao gaúcho, do modelo civilizatório aceito um tanto ingenuamente por Sarmiento, que parece ignorar a barbárie da civilizaçāo, denunciada com mais senso crítico, no caso brasileiro, por Euclides da Cunha. Estanislao del Campo parece divertix-se com as pretensōes de ambos os lados.

Para Udo Rukser, o encontro com Goethe nāo é para o mundo hispânico um fenômeno isolado, mas

fruto y culminación de un proceso prolongado por el que el mundo mundo hispánico hubo de pasar para superar su punto muerto y liberarse de su aislamiento. Hemos de desarrollor pus, las pasar pas con nes con Goehe siguto ex pueblos de habla española: esta transformación se conoce como europeización, porque se trata de la confrontación con el esprritu europeo tal como habfa surgido de la Ilustración. En este proceso se libra la batalla entre la tradición ortodoxa, que quisiera mantener su autoridad a todo trance, y la inteligencia, que se sabe libre y quiere hacer valer su autonomia. ${ }^{38}$

Goethe teria servido assim aos adversários da ortodoxia que o teriam celebrado como libertador. Dado o substrato popular do poema alemão, ele permite também aos hispanos retomar o fio da sua poesia medieval, atualizando estruturas e temas do cancioneiro e do romanceiro que haviam sobrevivido ao esplen-

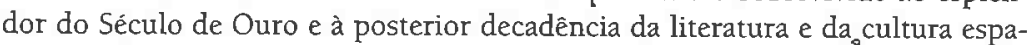
nholas sob a dominação obscurantista da Igreja. Mas, insiste Rukser, sem a veia filosófica de Goethe:

Y si el romanticismo alemán filosofaba por principio y mucho, nada de esto habia, en cambio, en el mundo hispanico. Ahi estriba la diferencia esencial. Mientras el romanticismo alemán sigue influyendo profundamente el presente con sus grandes temas del sueño y la noche y conmovió a otras literarturas europeas, precisamente gracias a su profundidad metafisica, mientras esperaba alcanzar en esta forma lo absoluto y enlazaba lo poético con la profundidad religiosa, el romanticismo español, en cambio, siguió siendo más superficial: le faltaba la melancolía que resultó tan peligrosa para los alemanes, pero que convirtio a su romanticismo en un gran acontecimiento.

O Romantismo espanhol, como forma de secularização e modernização, responde ao desejo de popularizar a literatura, servindo ao conhecimento e autoconhecimento dos indivíduos e do país. O traço é comum ao romantismo hispano-americano e brasileiro.

Na Espanha, as discussōes do Fausto calam fundo nos problemas da vida da época. Na América Latina, o componente político mais débil implica uma discussão menos apaixonada, mas está presente. Goethe e seu Fausto representam aí também a luta pela liberdade intelectual, contra os dogmas.

\footnotetext{
${ }^{38}$ Udo Rukser, Goethe en el mundo hispánico op. cit., p. 13
}

${ }^{39} \mathrm{Idem}, \mathrm{ibidem}$, p. 34
Como diz Rukser, não se trata de fazer do Fausto o protótipo do burguês, mas ele veicula uma visāo de mundo que só podia ser compreendida por uma sociedade burguesa e ilustrada.$^{40}$ A modernidade do Fausto implica uma antinomia entre vida e saber. E isso expressaria a experiência do homem modemo, eternamente cindido. ${ }^{41}$

Fausto é visto como moderno por excelência porque é a síntese entre o romântico e o clássico, o pagão e o cristão, o antigo e o modemo. Nicolás Jimenez caso exemplar citado por Rukser, teria captado em Goethe a cooperaçāo harmônica do céu e da terra no pulso de uma só vida, tal como só podia representá-lo um poeta moderno.

Para Octavio Paz, o mito fáustico, em Goethe, é uma espécie de espelho do espírito ocidental. E se Goethe é uma figura entre dois mundos, o lado que otha para o futuro é romântico, do primeiro Fausto. ${ }^{42}$

Se, para a Espanha, a Alemanha servia assim à bandeira do "europeizemonos", para a América Latina, a aproximação da cultura alemã, também filtrada pela França e Inglaterra, servia ao lema "desespanholizemo-nos". Como no Brasil: "libertemo-nos de Portugal". 43

Udo Rukser chama atenção para que, no caso da América Latina, é preciso considerar que, mais do que a Espanha ortodoxa, viveu longamente isolada da Europa, pela distância e pelas condiçōes naturais desfavoráveis, sofrendo o monopólio mercantil e o precário desenvolvimento intelectual, com suas estruturas educacionais atrasadas. Zum Felde nos diz que tudo é dogma no final do periodo colonial, regra, cânon, fórmula. E que para se ter acesso à ilustraçāo era preciso sair do mundo hispânico. A França e a Inglaterra constituíram, assim, verdadeiras pontes para uma cultura mais atual e aberta.

Da Independência em diante, tomamos na América uma cultura pronta de outros centros culturais. Um desejo de universalidade, para além da simples revolta contra a metrópole, é o que se revela aí. Mas a adoção de novas formas é, na maior parte das vezes, imitaçāo servil, com perda da tradição e pouca originalidade. Se levarmos em consideração essa opinião corrente na crítica do período, a originalidade de Del Campo aparece nitidamente, pois não deixa de tematizar esse processo todo, utilizando os modelos, do ponto de vista do gaúcho, a partir da gauchesca que era um gênero criado já há mais de meio século.

Resolve também, a seu modo, o problema da língua, pois enquanto o jovem que se instruía na América espanhola entre 1830 e 1880 nāo sabia concordar a sua forma nativa de falar com as formas literárias dos escritores franceses que lia e imitava, no caso dos gauchescos a língua local era trabalhada como tal para, juntamente com a língua literária, construir um objeto híbrido bastante verossímil. Ao mesclar o modelo de Goethe e da ópera com a tradiçāo da gauchesca, Estanislao del Campo consegue escapar da norma geral, conforme a define Udo Rukser:

${ }^{40}$ Idem, ibidem, p. 123.

${ }^{41}$ Idem, ibidem, p. 142

${ }^{42}$ Octvio Paz, El arco y la lira, México, Fondo de Cultura Económico, 1956

${ }^{43}$ Ver a esse respeito Antonio Candido, A formaçăo da literatura brasileira, op. cit.; e Pierre Rivas, "Paris, capital do século XIX", in Literatura e história na América Latina, São Paulo, Edusp, 1993. 
Pero puesto que no podemos escapar a nuestro pasado, aun queriendolo, el hispanoamericano cae en una contradicción interior que se percibe en la literatura como elemento paralizante durante todo el siglo siguiente. $Y$ ao pretender apoderarse en el más breve tiempo posible del legado europeo que le habia sido escamoteado, todos los problemas actuales imumpen de golpe en el continente y provocan una enorme confusión.

No se deja madurar nada, pues hay que seguir en el acto toda nueva moda, para demostrar ast la propia capacidad. Cada vez más los intelectuales latinoamericanos se aferran al modelo francés. Y ast, si en la época colonial la literatura de America Latina fue una simplificación excesiva de la española, en el siglo XIX es, en cambio, ante todo, una imitación de la francesa, que imumpe además con una avalancha de traducciones. En tanto no pueden eliminar su herencia española, los latinoamericanos compensan el conflicto con su afecto por Europa, es decir, por Francia."

Pode-se dizer que, no Fausto de Estanislao, a dependência francesa se atenua, embora se conserve, quando se cruza com a tradiçāo gauchesca. $O$ poema muda ópera de gênero e muda Goethe de gênero mais uma vez. Segue sendo um gênero semidramático, mas tudo se reorganiza em torno das normas dessa poesia que, a essa altura, como alertam Borges e Ángel Rama, já estāo suficientemente consolidadas num sistema coeso.

A acusação corrente de artificialidade para romances escritos sobre temas americanos, que dão a impressão de terem sido escritos por europeus, é a mesma feita a muitos românticos brasileiros. Houve quem fizesse essa acusaçāo a Del Campo, Leopoldo Lugones entre esses, como vimos. Mas, tal como Borges, julgamos que, nesse caso, não procede a crítica. Não nos parece artificial a ida do gaúcho à ópera, porque encontra uma forma para expressar-se que convence, traduzindo a ópera nos seus códigos, e isso é o que conta mais do que a sua improvável entrada no Colón. Depois que entra, o que importa é como fica e como sai. O problema, que Estanislao resolve muito bem, é manter Anastasio el Pollo na ópera e manternos atentos às suas impressōes. Isso se consegue com arte, com a dosagem equilibrada de gauchismos, das palavras às comparaçōes e à visão geral do mundo Afinal, se a literatura culta ainda nāo filosofava nesse lado do mar, o gaúcho já se perguntava sobre temas básicos da existência, como ficará mais claro, pouco depois, com Martín Fierro.

Segundo Alfonso Reyes, na América, chegamos demasiado tarde para tudo e, por isso, nossos escritores passam por alto as heranças recebidas:

necesitan abreviar la evolución para estar al corriente... En esta confusión, la música, la conciencia no puede llegar a la armonia...Y por sobre este mar revuelto, se atree el faro a proyectar su luz? Qué quiere Goethe entre nosotros? Aquello que el faro hace siempre: señalar la dirección- pese a todo: señalar ta dirección -, aunque parezca sarcasmo, señalar la dirección, porque todo ideal es sarcasmo. ${ }^{45}$

O Fausto de Estanislao faz parte desse processo. A começar pelo fato de que é escrito muito de afogadilho, sendo publicado alguns meses depois da apresentação da ópera em Buenos Aires. Mas Estanislao deve também ter lido Goethe, mesmo

${ }^{45}$ Udo Rukser, Goethe en el mundo hispanico, op.cit, p. 51.

${ }^{45}$ Apud Udo Rukser, Goethe en el mundo hispánico, op. cit., p. 55. que seja na traduçāo espanhola, feita do francês nos anos 60. Há indícios disso tanto na sua biografia de homem culto quanto no poema. Nesse, uma análise mais atenta, como a dos excursos, mostra que eles parecem querer compensar algo do que se perdeu na passagem do texto do Goethe ao livreto da ópera. Digamos que esses excursos expressam o lado mais diretamente sério de um poema que tem muito de "broma", como notou Borges, ficando essa mais perceptível nos diálogos e na idéia geral que Pollo e Laguna fazem do mythos de Fausto. Mas é justamente na junçāo desses dois pólos que o poema ganha originalidade, assinalando, pela incorporação local do tema do pactário, a universalizaçāo da cultura gauchesca. $O$ paradoxo é apenas aparente. Para nāo ser postiço, havia que agauchar o drama fáustico, mas para agauchá-lo, havia que tomar a distância de uma ironia compatível com a operação de rebaixamento paródico necessária à expressão da descoberta de que nem os doutores estāo livres das voltas do diabo.

Tudo isso, algum tempo depois de El Facundo, e na pena de um liberal, desmente a fama do gaúcho bárbaro e mostra que ele também pode usufruir da arte, traduzindo-a a seu modo, como aliás se tem feito, desde que o primeiro homem encontrou o primeiro desenho numa caverna, desde que o primeiro ouvinte escutou uma história de um narrador, desde que o primeiro leitor reagiu a uma história escrita. Por que tirar esse direito ao gaúcho? O direito de interpretar, de assimilar e reproduzir reinventando? A brincadeira de Estanislao tem esse lado sério e liberador, a contrapelo da própria ideologia que professava. E isso pode explicar um pouco do frescor do poema, mais de um século depois. 